\title{
In Situ Immunoassay (ISIA) of Field Grapefruit Trees Inoculated with Mild Isolates of Citrus tristeza virus Indicates Mixed Infections with Severe Isolates
}

\author{
Youjian Lin, Department of Plant Protection, Fujian Agriculture and Forest University, Fuzhou, Fujian 350002, P. \\ R. China; Phyllis A. Rundell, Biologist, Indian River Research and Education Center, University of Florida, Fort \\ Pierce 34945; and Charles A. Powell, Professor, Indian River Research and Education Center, University of Flor- \\ ida, Fort Pierce 34945
}

\begin{abstract}
Lin, Y., Rundell, P. A., and Powell, C. A. 2002. In situ immunoassay (ISIA) of field grapefruit trees inoculated with mild isolates of Citrus tristeza virus indicates mixed infections with severe isolates. Plant Dis. 86:458-461.

Ten grapefruit trees that had been inoculated with a mild isolate of Citrus tristeza virus (CTV) and maintained in the field for 18 years were found in a previous study to be declining and infected with severe isolates of CTV, or symptomless and infected with mild isolates of CTV, using enzyme-linked immunosorbent assay (ELISA). They were assayed with an in situ immunoassay (ISIA) procedure using monoclonal antibodies 17G11 (reacts with most Florida isolates of CTV) and MCA13 (reacts with severe, but not Florida mild isolates of CTV). All the grapefruit trees were $17 \mathrm{G} 11$ positive by ELISA and ISIA. The five trees that showed moderate decline symptoms were MCA13 positive by ELISA and ISIA. The five symptomless trees were MCA13 negative by ELISA. However, four of the five symptomless trees were MCA13 positive by ISIA, which showed that ISIA with MCA13 had greater sensitivity in detecting severe CTV isolates than ELISA. These results suggested that the cross-protected grapefruit trees, regardless of symptoms, were infected with both mild and severe isolates of CTV.
\end{abstract}

Additional keywords: cross protection

Citrus tristeza virus (CTV), a member of the genus Closterovirus with an approximate 20-kb genome and long flexuous filamentous particles, is distributed worldwide and causes economically important diseases wherever citrus is grown $(2,3)$. The virus can induce stunting, slow decline, quick decline, stem pitting, or no symptoms, depending on the virus isolate, environmental conditions, citrus scion cultivar, and rootstock. The most destructive damage is the induced decline in scions grafted to sour orange (Citrus aurantium L.) rootstock and the severe stem pitting and loss of plant vigor on oranges and grapefruit regardless of the rootstock $(4,5)$.

Cross-protection has been considered a potentially effective strategy to reduce losses due to CTV infection $(6,12,16)$. In Brazil, cross-protection has been used commercially for many years to control

Corresponding author: Charles A. Powell

E-mail: CAPowell@mail.ifas.ufl.edu

Florida Agricultural Experiment Station Journal Series: R-07785.

Accepted for publication 18 December 2001.

Publication no. D-2002-0301-01R

() 2002 The American Phytopathological Society
CTV-stem pitting isolates on sweet orange by preinoculating trees with mild isolates $(10-12,14)$. The same strategy is now a part of South Africa's citrus cultivar improvement program to reduce stem-pitting injury in grapefruit (3). Deliberate use of propagating sources infected with mild CTV isolates, which protect against natural infection by more severe isolates, has been tested in many other areas (16-18). The effect of cross-protection on grapefruit from decline-inducing isolates of CTV was also evaluated in Florida. The results suggested that certain mild isolates of CTV can provide long-term protection of grapefruit trees on sour orange rootstock from decline-inducing isolates of CTV $(17,18)$. Serological evidence also supported the effects of cross-protection on CTV control. When challenged with a severe isolate, the trees preinoculated with mild isolates had lower enzyme-linked immunosorbent assay (ELISA) values (using severe-isolate specific monoclonal antibodies) as compared with the unprotected, challenged control trees (19). In some instances, the crossprotection provided by certain mild strains may break down in field grapefruit trees (16-18). However, it was found that some of the cross-protected grapefruit trees were symptomless and reacted with monoclonal antibody (MAb) 17G11 (reacts with most Florida CTV isolates) but not MAb MCA13 (reacts with Florida declineinducing isolates of CTV, but does not react with Florida non-decline-isolates of CTV), while the others were in decline and reacted with MAbs 17G11 and MCA13 in ELISA (17). In situ immunoassay (ISIA) is a new immunoassay procedure that directly detects CTV within the infected tissues of citrus (7). In this study, the ISIA procedure was used to investigate cross-protected grapefruit trees that were symptomless or declining with CTV strain-specific MAb MCA13, broad-range MAb 17G11, and a combination of both antibodies.

\section{MATERIALS AND METHODS}

Source plants. Ten grapefruit trees that were preinoculated with a mild isolate (DD102bb) of CTV in 1979 were selected based on both symptoms and previous ELISA results. Among them, five trees were symptomless and had been diagnosed with mild CTV, and another five trees were in moderate decline (thin foliage but still producing new growth) and had been diagnosed with severe CTV, according to previous results by ELISA (18). Three young stems from each of these trees were collected and assayed in this study with ISIA and ELISA. A severe CTV isolate (T-36) and a mild isolate (T-30) originally obtained by aphid transmission (15) and maintained in Citrus excelsa in a quarantine greenhouse were used as positive control isolates. Healthy grapefruit seedlings maintained in a greenhouse were used as negative controls.

Antisera. CTV polyclonal antiserum (PCA) 1212 and MAbs 17G11 (8) and MCA13 were used in this study as previously described (7). In Florida, MCA13 reacts with decline-inducing field isolates of CTV, but not mild isolates; whereas 17 G11 reacts with all field isolates. The concentration of immunoglobulin (Ig)G of PCA 1212 used in the test was at $1 \mu \mathrm{g} / \mathrm{ml}$ as coating antibody in ELISA. MCA13 and 17 G11 were used as intermediate antibodies in ELISA and as direct binding antibodies in ISIA (7). The labeled secondary antibody, alkaline phosphatase conjugated 
goat anti-mouse Ig $(\mathrm{H}+\mathrm{L})$-alkaline phosphatase, was purchased from a commercial company (Sigma, St Louis, MO).

ELISA. Indirect double antibody sandwich (DAS-I) ELISA as described previously (7) was performed in this study to assay the selected cross-protected grapefruit trees. Positive reactions were defined as an $\mathrm{OD}_{415 \mathrm{~nm}}$ significantly higher $(5 \%$ level) than the healthy control.

ISIA. A slightly modified ISIA procedure (7) was used to assay the crossprotected grapefruit trees with MAbs 17G11, MCA13, and a combination of 17G11 and MCA13. Three sequential sections, about $200 \mu \mathrm{m}$ in thickness, were cut from each stem of infected or healthy citrus plants with a razor blade, fixed with $70 \%$ ethanol for $20 \mathrm{~min}$, and washed with sterile water for $10 \mathrm{~min}$. The sections were fastened to a slide in order with a piece of double-stick tape. The same sides of the sections were in the same direction on the slide. The sections were treated with CTV MAbs MCA13, 17G11, and a combination of both antibodies. About 30 to $50 \mu \mathrm{l}$ of CTV-specific antibodies, 17G11 (undiluted cell culture fluid, approximately $1 \mu \mathrm{g} / \mathrm{ml}$ ), MCA13 at $1 \mu \mathrm{g} / \mathrm{ml}$ in PBST-B (7), or a combination of $17 \mathrm{G} 11$ and MCA13 were added to cover the sections. After incubation for $1 \mathrm{~h}$ at $37^{\circ} \mathrm{C}$ or room temperature, the sections were washed twice with PBST-PVP (7), $5 \mathrm{~min}$ for each, then incubated with 30 to $50 \mu$ l of alkaline phosphatase conjugated goat anti-mouse $\mathrm{Ig}$ $(\mathrm{H}+\mathrm{L})-\mathrm{AP}$ for $1 \mathrm{~h}$ at $37^{\circ} \mathrm{C}$ or room temperature. The sections were washed again with PBST-PVP for $5 \mathrm{~min}$ and with TTBS buffer (7) for $5 \mathrm{~min}$. The reactions were developed by incubating the sections with 30 to $50 \mu \mathrm{l}$ of a freshly prepared NBTBCIP substrate mixture (7) for 10 to 15 min. The reactions were stopped by carefully washing the sections with sterile water for about $5 \mathrm{~min}$, then observed under a light microscope at $\times 100$ magnification and recorded. A positive reaction was the development of a purple color in the phloem tissue of stems, and a negative reaction was no purple color in the phloem tissue of stems. The differences in virus titers were expressed by the reaction density (purple color) in the same locations of phloem tissues to different antibodies among the cross-protected grapefruit trees. A rating of 0 to 6 was used to categorize the reaction density, with 6 being the most dense. A rating of 0 indicated no purple "spots", a rating of 1 indicated only 2 or 3 purple spots, a rating of 2 indicated about twice as many spots as 1 , a rating of 3 about twice as many as 2 , etc. Three stems of each tree were assayed with three replications per stem.

\section{RESULTS}

Comparison of ISIA and ELISA. With MAb MCA13, standard curves were constructed by comparing ELISA and ISIA readings from adjacent stem sections on greenhouse-grown grapefruit inoculated with CTV severe isolate T36. Stem sections that produced ISIA ratings of $1,2,3$, 4, 5, and 6 gave ELISA values that were about $1 \times, 1 \times, 2 \times, 3 \times, 4 \times$, and $5 \times$ higher than healthy controls, respectively. With MAb 17G11, standard curves using the same samples as used for MCA13 gave ELISA values about $1 \times, 5 \times, 15 \times, 50 \times$, and $50 \times$ higher than healthy controls, respectively, for ISIA rating 1 to 6 . For examples of the rating scale see Figure 1.

Detection of CTV in cross-protected grapefruit plants by ELISA and ISIA. Positive controls were positive and healthy
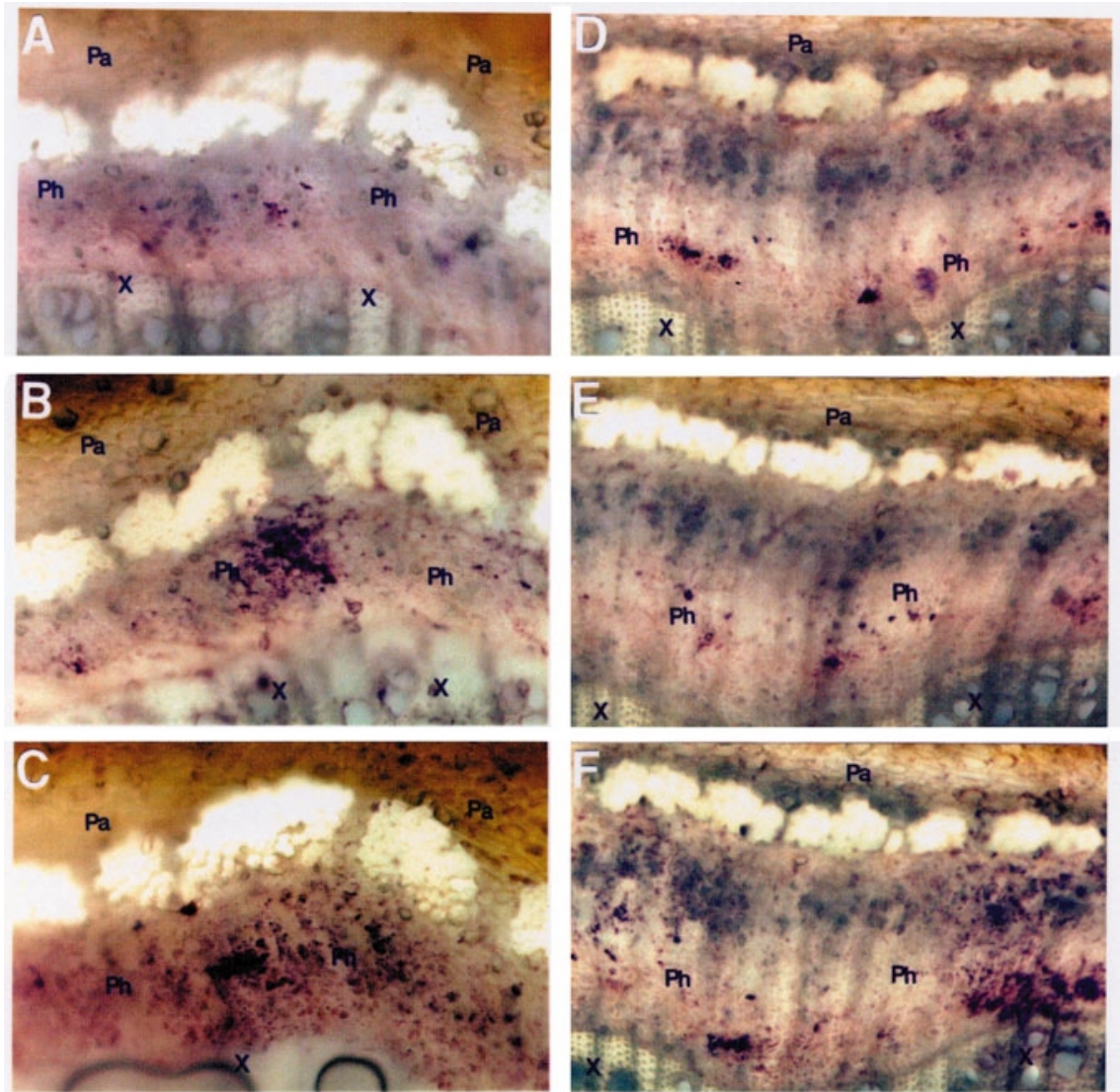

control trees were negative for CTV infection (Table 1). The reaction of CTV antigens to CTV MAbs in ISIA was demonstrated by the development of a purple color in the phloem tissue of CTV-infected plants (Fig. 1A to $\mathrm{F}$ and $\mathrm{H}$ ). No purple color was observed in healthy citrus plants (Fig. 1G). CTV was detected in both the five declining and five nondeclining field grapefruit trees and positive control plants by ELISA and ISIA procedures with MAb 17G11 (Table 1). There were differences in reactions of the grapefruit trees to $\mathrm{MAb}$ MCA13 between ELISA and ISIA. The five grapefruit trees that showed moderate decline symptoms were positive to $\mathrm{MAb}$

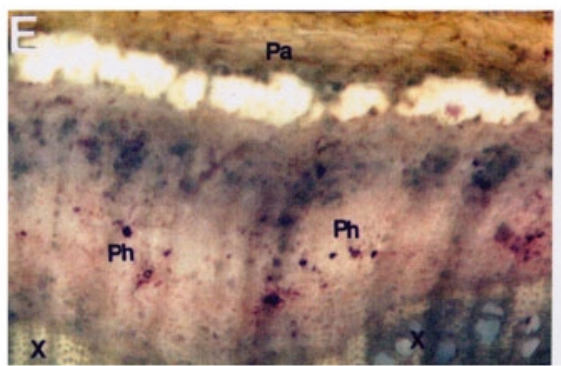

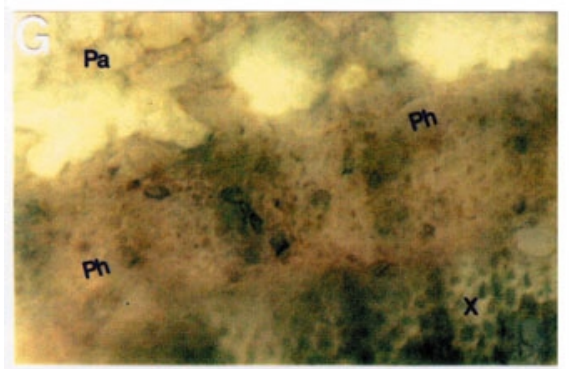

Fig. 1. In situ immunoassay (ISIA) reactions of Citrus tristeza virus (CTV) in the sequential sections of cross-protected grapefruit trees that were symptomless or in moderate decline. A, B, and C, sequential sections from a symptomless cross-protected grapefruit tree. A, reacted with MCA13 $(\times 200)$; B, reacted with 17G11 $(\times 200)$; C, reacted with a combination of MCA13 and 17G11 (×200). $\mathbf{D}, \mathbf{E}$, and F, sequential sections from a cross-protected grapefruit tree with moderate decline symptoms. D, reacted with MCA13 $(\times 200)$; E, reacted with $17 \mathrm{G} 11(\times 200)$; $\mathbf{F}$, reacted with a combination of MCA13 and 17G11 $(\times 200)$. G, sections of healthy grapefruit plants, showing no reaction in ISIA with a combination of MCA13 and 17G11 $(\times 200)$. H, a close look at reaction of CTV antigens with CTV-specific antibodies (MAb 17G11) in the phloem tissues of citrus in ISIA $(\times 400)$. Pa: parenchyma; $\mathrm{Ph}$, phloem tissue; $\mathrm{X}$, xylem. Using an ISIA rating scale, the ratings for $\mathbf{A}, \mathbf{B}, \mathbf{C}, \mathbf{D}, \mathbf{E}$, and $\mathbf{F}$ were $1,4,5,3,2$, and 4 , respectively. 
MCA13 in ELISA. They were also positive to MAb MCA13 in ISIA. However, even though none of the five symptomless grapefruit trees were positive for CTV with MAb MCA13 in ELISA, four of the five were positive by ISIA using MAb MCA13. All of the grapefruit trees were positive to MAb 17G11 alone and a combination of MAb 17G11 and MAb MCA13 in ISIA.

Differences in virus immunoreactivity between symptomless and declining grapefruit plants in ISIA reactions. Differences in virus immunoreactivity between the symptomless and the declining cross-protected grapefruit trees to MAbs 17G11, MCA13, and a combination of the antibodies were found in the sequential sections from the same stems using ISIA. The virus immunoreactivity in the symptomless grapefruit trees measured by MAb MCA13 was usually much lower than that measured by MAb 17G11 (Fig. 1A and B, Table 1). The reaction densities with MAb MCA13 from grapefruit trees in moderate decline were usually higher than those of symptomless trees (Fig. 1D and E, Table 1). In some cases, the reaction densities with MCA13 to symptomatic trees were roughly the same as that with MAb 17G11. The ISIA density measured by a combination of MAbs was approximately equal to the sum of the reaction densities measured by MAbs MCA13 and MAb 17G11 separately (Fig. $1 \mathrm{C}$ and $\mathrm{F}$, Table 1).

\section{DISCUSSION}

The results suggest that most of the cross-protected grapefruit trees, both symptomatic and symptomless, were infected with mixed populations of preinoculated mild isolate and the naturally occurring field decline severe isolates of CTV. Mild and severe isolates of CTV can occur in the same grapefruit trees $(9,16)$. The

Table 1. Comparison of enzyme-linked immunosorbent assay (ELISA) and in situ immunoassay (ISIA) for detecting Citrus tristeza virus (CTV) in cross-protected grapefruit trees

\begin{tabular}{|c|c|c|c|c|c|c|}
\hline \multirow{2}{*}{$\begin{array}{l}\text { Tree } \\
\text { code }\end{array}$} & \multirow[b]{2}{*}{ Symptoms } & \multicolumn{2}{|c|}{ ELISA $(\text { OD) })^{x}$} & \multicolumn{3}{|c|}{ ISIA (density of reactions)y } \\
\hline & & MCA13 & $17 G 11$ & MCA13 & $17 G 11$ & MCA13+17G11 \\
\hline $1-5$ & None & $0.072 \mathrm{a}^{\mathrm{z}}$ & $2.072 \mathrm{~d}$ & $1 \mathrm{~b}$ & $4 \mathrm{~b}$ & $5 \mathrm{bc}$ \\
\hline $2-38$ & None & $0.047 \mathrm{a}$ & $0.167 \mathrm{~b}$ & $0 \mathrm{a}$ & $3 \mathrm{~b}$ & $3 \mathrm{~b}$ \\
\hline $2-49$ & None & $0.068 \mathrm{a}$ & $0.291 \mathrm{~b}$ & $2 \mathrm{c}$ & $4 \mathrm{~b}$ & $6 \mathrm{c}$ \\
\hline $3-23$ & None & $0.069 \mathrm{a}$ & $2.009 \mathrm{~d}$ & $2 \mathrm{c}$ & $4 \mathrm{~b}$ & $6 \mathrm{c}$ \\
\hline $3-73$ & None & $0.054 \mathrm{a}$ & $0.532 \mathrm{c}$ & $1 \mathrm{~b}$ & $3 \mathrm{~b}$ & $4 \mathrm{bc}$ \\
\hline $1-19$ & Decline & $0.186 b c$ & $0.941 \mathrm{c}$ & $4 \mathrm{~d}$ & $3 \mathrm{~b}$ & $6 \mathrm{c}$ \\
\hline $1-32$ & Decline & $0.123 \mathrm{~b}$ & $2.482 \mathrm{~d}$ & $4 d$ & $3 \mathrm{~b}$ & $6 \mathrm{c}$ \\
\hline $2-12$ & Decline & $0.205 b c$ & $2.671 \mathrm{~d}$ & $4 \mathrm{~d}$ & $4 \mathrm{~b}$ & $4 \mathrm{bc}$ \\
\hline $3-13$ & Decline & $0.248 \mathrm{c}$ & $2.735 \mathrm{~d}$ & $3 \mathrm{~cd}$ & $3 \mathrm{~b}$ & $5 \mathrm{bc}$ \\
\hline $3-44$ & Decline & $0.132 b c$ & $0.294 \mathrm{~b}$ & $4 \mathrm{~d}$ & $4 \mathrm{~b}$ & $6 \mathrm{c}$ \\
\hline T-36 & None & $0.262 \mathrm{c}$ & $2.638 \mathrm{~d}$ & $4 \mathrm{~d}$ & $4 \mathrm{~b}$ & $6 \mathrm{c}$ \\
\hline $\mathrm{T}-30$ & None & $0.076 \mathrm{a}$ & $1.996 \mathrm{~d}$ & $0 \mathrm{a}$ & $4 \mathrm{~b}$ & $4 b c$ \\
\hline Healthy & None & $0.061 \mathrm{a}$ & $0.050 \mathrm{a}$ & $0 \mathrm{a}$ & $0 \mathrm{a}$ & $0 \mathrm{a}$ \\
\hline
\end{tabular}

${ }^{x}$ Each optical density (OD) value is the mean of six assays (three stems per tree, conducted twice). MCA13, a CTV strain-specific monoclonal antibody, see detail in text. 17G11, a CTV broad range monoclonal antibody, see detail in text.

${ }^{\mathrm{y}}$ ISIA of 0 to 6 indicates the density of the reaction (amount of purple color), with 6 being the most dense. Each number is the average of nine assays (three stems per tree, conducted three times) rounded to a whole number.

${ }^{\mathrm{z}}$ Numbers in a column followed by different letters are significantly different (5\% level) by Duncan's multiple range test. to detect different strains or isolates, mild and severe, of CTV in a mixed infection with strain-specific monoclonal antibodies. However, more work is needed to extensively evaluate ISIA in detection of different strains or isolates, mild and severe, of CTV in a mixed infection with strainspecific monoclonal antibodies. More strain-specific antibodies of CTV need to be developed for the detection of different CTV isolates or strains in mixed infected citrus plants by ISIA procedure and other serological methods.

In order to effectively evaluate and use cross protection as a strategy against the infection of severe isolates of CTV, it is necessary to recognize why there are two kinds of cross-protected citrus plants, symptomless and declining, in the same cross-protection experiment. Although our results suggest that it is due to difference in concentration of different antigens of mild and severe isolates of CTV in the crossprotected plants, the reason that antigens of different isolates of CTV occur at different concentrations is unknown. Viral antigen concentrations may influence the symptoms of different individuals or varieties of citrus, and different individuals or varieties of citrus may influence the expression of different isolates of CTV. The influence of host plants on dsRNA patterns and concentrations of different isolates of CTV has been reported $(1,9,13)$. However, the influence of different individuals or varieties of citrus on cross protection and the mechanisms of expression of CTV isolates in host plants need to be further investigated.

\section{ACKNOWLEDGMENTS}

We thank M. S. Garnsey for kindly providing CTV antibodies PCA1212 and MAb MCA13.

\section{LITERATURE CITED}

1. Albiach, M. R., da Graca, J. V., van Vuuren, S. P., Guerri, J., Cambra, M., Laigret, F., and Moreno, P. 1996. The effects of different hosts and natural disease pressure on molecular profiles of mild isolates of citrus tristeza virus (CTV). Pages 147-153 in: Proc. Conf. Int. Org. Citrus Virol., 13th. J. V. Graca, P. Moreno, and R. K. Yokomi, eds. IOCV, Riverside, CA

2. Bar-Joseph, M., Garnsey, S. M., Gonsalves, D., Moscovitz, M., Purcifull, D. E., Clark, M. F., and Loebenstein, G. 1979. The use of enzyme-linked immunosorbent assay for the detection of citrus tristeza virus. Phytopathology 69:190-194.

3. Bar-Joseph, M., Marcus, R., and Lee, R. F. 1989. The continuous challenge of citrus tristeza virus control. Annu. Rev. Phytopathol. 27:297-316.

4. Garnsey, S. M., Gonsalves, D., and Purcifull, D. E. 1978. Rapid diagnosis of citrus tristeza virus infections by sodium dodecyl sulfateimmunodiffusion procedures. Phytopathology 68:88-95.

5. Garnsey, S. M., Permar, T. A., Cambra, M., and Henderson, C. T. 1993. Direct tissue blot immunoassay (DTBIA) for detection of citrus tristeza virus (CTV). Pages 39-50 in: Proc. Conf. Int. Org. Citrus Virol., 12th. P. Moreno, J. V. da Graca, and L. W. Timmer, eds. IOCV, Riverside, CA.

6. Giacometti, D. C., and Araujo, C. M. 1965. 
Cross protection from tristeza in different species of citrus. Pages 14-17 in: Proc. Conf. Int. Org. Citrus Virol., 5th. W. C. Price, eds. University of Florida Press, Gainesville.

7. Lin, Y., Rundell, P. A., Xie, L., and Powell, C. A. 2000. In situ immunoassay for detection of Citrus tristeza virus. Plant Dis. 84:937-940.

8. Manjunath, K. L., Hooker, M., Pappu, H. R., Pappu, S. S., Powell, C. A., Bar-Joseph, M., Niblett, C. L., and Lee, R. L. 1996. Synthesis of a functional single-chain antibody against citrus tristeza virus closterovirus in bacteria. Pages 38-46 in: Proc. Conf. Int. Org. Citrus Virol., 13th. J. V. Graca, P. Moreno, and R. K. Yokomi, eds. IOCV, Riverside, CA.

9. Moreno, P., Guerri J., Ballester-Olmos, J. F., Fuertes-Polo, C., Albiach, R., and Martinez, M. 1993. Variations in pathogenicity and double-stranded RNA (dsRNA) patterns of citrus tristeza virus isolates induced by host passage. Pages 39-50 in: Proc. Conf. Int. Org. Citrus Virol., 12th. P. Moreno, J. V. da Graca, and L. W. Timmer, eds. IOCV, Riverside, CA.

10. Muller, G. W., and Costa, A. S. 1968. Further evidence on protective interference in citrus tristeza. Pages 71-78 in: Proc. Conf. Int. Org. Citrus Virol., 4th. J. F. L. Childs, eds. University of Florida Press, Gainesville.

11. Muller, G. W., and Costa, A. S. 1977. Tristeza control in Brazil by preimmunization with mild strains. Proc. Int. Soc. Citric. 3:868-872.

12. Muller, G. W., Sobrinho, J. T., Pompeu, J., and Costa, A. S. 1984. Cross protection increase yield of tristeza tolerant sweet oranges. Proc. Int. Soc. Citric. 1:340-350.

13. Nickel, O., Santos Filho, H. P., and Vilarinhos, A. D. 1996. Segregation of citrus tristeza virus strains by graft propagation. Pages 6470 in: Proc. Conf. Int. Org. Citrus Virol., 13th. J. V. Graca, P. Moreno, and R. K. Yokomi, eds. IOCV, Riverside, CA.

14. Passos, O. S., Santos Filho, H. P., Silva, M. J., and Caldas, R. C. 1992. Cross protection as a procedure for improving 'Pera' sweet orange. Soc. Citric. 2:772-773.

15. Permar, T. A., Garnsey, S. M., Gumpf, D. J., and Lee, R. T. 1990. A monoclonal antibody that discriminates strains of citrus tristeza vi- rus. Phytopathology 80:224-228.

16. Powell, C. A., Pelosi, R. R., and Cohen, M. 1990. The breakdown of cross-protection against severe Florida strains of CTV. (Abstr.) Phytopathology 80:986.

17. Powell, C. A., Pelosi, R. R., and Cohen, M. 1992. Superinfection of orange trees containing mild isolates of citrus tristeza virus with severe Florida isolates of citrus tristeza virus. Plant Dis. 76:141-144.

18. Powell, C. A., Pelosi, R. R., Rundell, P. A., and Cohen, M. 1998. Cross-protection of grapefruit from decline-inducing isolates of citrus tristeza virus. (Abstr.) Phytopathology 88:S73.

19. Rocha-Pena, M. A., Lee, R. F., Permar, T. A., Yokomi, R. K., and Garnsey, S. M. 1991. Use of enzyme-linked immunosorbent and dotimmunobinding assay to evaluate two mild strains cross protection experiments after challenge with a severe citrus tristeza virus isolate. Pages 93-102 in: Proc. Conf. Int. Org. Citrus Virol., 11th. R. H. Brlansky, R. F. Lee, and L. W. Timmer, eds. IOCV, Riverside, CA. 